\title{
Role of Spouses In Marital Stability As Perceived By Educated Couples In Kwara State,Nigeria
}

\author{
Dr. M.F. Dada, M.R. Adetutu (M.Ed), S.O. Bada (M.Ed), Dr. K.B Sanni \\ Department Of Counsellor Education,Faculty Of Education,Unilorin \\ Nigerian Navy Secondary School, Borokiri, Department Of Guidance \& Counselling(Port Harcourt) \\ Department Of Arts \& Social Sciences Education,Faculty Of Education,Unilorin \\ Department Of Educational Foundation, Guidance \& Counselling,Faculty Of Education,Uniuyo
}

\begin{abstract}
The Paper Investigated The Role Of Spouses In Marital Stability As Perceived By Educated Couples In Kwara State. A Total Of 300 Educated Couples Consisting Of 132 Males And 168 Females Were Selected Using A Simple Random Sampling Technique. Data Were Collected From The Respondents Using An Instrument Titled "Role Of Spouses In Marital Stability Questionnaire" (Rsimsq). The Four Null Hypotheses Generated Were Analyzed Using The T-Test And Analysis Of Variance (Anova) At 0.05 Alpha Level Of Significance, Where The Result Of Anova Showed A Significant Difference, Duncan Multiple Range Test (Dmrt) Statistics Was Used To Determine The Group(S) That Contributed To The Significant Difference. The Study Identified The Major Role Of Spouses In Marital Stability As Sexual, Financial And Domestic With Mean Scores Of 19.10, 19.09 And 16.15 Respectively. The Study Indicated No Significant Difference In The Perception Of The Role Of Spouses In Marital Stability Based On Length Of Years In Marriage. However, There Was A Significant Difference In The Perception Of The Role Of Spouses In Marital Stability Based On Gender, Highest Educational Qualification And Age. Based On The Findings Recommendations Were Made For Implementation.
\end{abstract}

Key Words: Role, Spouses And Marital Stability

\section{INTRODUCTION}

Marriage Is The Legal Union Which Involves A Man And A Woman Giving Themselves To Each Other As Helpmates For Procreation And Training Of Children. According To Nwoye (1991) As Reported By Kanu And Anyanwu (2006), Marriage In Itself Is A Sacred And Permanent Contract Which Is Assumed To Be Enacted When Two People (Usually A Man And A Woman) Decide On Their Own Accord And In The Presence Of, At Least, Two Witnesses To Exchange The Formal Consent To Live A Life Of Vocation Of Love And Sharing For Each Other, For The Purpose Of Promoting Their Mutual Growth And Welfare As Persons In Their Journey Together Through Life. Dada And Idowu (2006) Opined That Some Factors That Can Enhance Marital Stability Includes Effective Communication Between Couples, Endurance At All Times By Both Spouses, Prudence On The Part Of The Spouses, Praying Together Amongst Others. In Other Words, The Aforementioned Factors Plays An Important Role In Marital Stability Of Any Family. It Is Some Of These Factors That The Present Study Investigated To See How They Stabilize Marriage As Perceived By Educated Couples In Kwara State.

\section{STATEMENT OF THE PROBLEM}

Although Marriage Is A Union Which Is Intended To Make The Couple Concerned One And Indivisible, There Are Sometimes, Circumstances That Leads To Misunderstanding And If Not Checked In Time, Will Ultimately Lead To Marital Instability Because It Can Lead To Divorce (Kanu And Anyanwu, 2006). In Addition, Mba (1994) Opined That Marriage In Many Parts Of The World Is So Fraught With Pain, Disruption, Heartbreak And Anxiety That The Family Or Family Life Appears To Be On The Brink Of A Total Collapse. Furthermore, The Scenario Of Crisis In Marriage Painted By Mba Is Informed By The Fact That Individual Differences Exists Between Every Married People (Kanu And Anyanwu, (2006).

From Available Literature, Most Of The Previous Studies Was Based On Marriage Related Area, For Instance, Distress Signals In Marriage And Family Life. Implications For Guidance And Counselling (Kanu And Anyanwu, 2006). Resolving Marital Conflict Through Counselling (Gbenda And Akume, 2002), Impact Of Pre-Marital Guidance On Undergraduates' Attitude Towards Family Stability (Onwuasoanya, 2006), 
Counselling For Marital Stability (Ime, 2006). None Of The Aforementioned Scholars Carried Out Their Studies In Kwara State On The Role Of Spouses In Marital Stability As Perceived By Educated Couples.

Considering The Aforementioned Problems That Usually Lead To Marital Instability And The Gaps

Created By Previous Researchers In The Area Of Study, The Researchers Were Challenged And Consequently Sought To Conduct A Study On The Role Of Spouses In Marital Stability As Perceived By Educated Couples In Kwara State. Furthermore, Educated Couples Have Been Used For The Study By The Researchers Because They Would Be Able To Respond More Accurately To The Items In The Questionnaire Using Their Wealth Of Experiences Having Known The Importance Of The Study. In The Study, Comparisons Were Made Based On Gender, Highest Educational Qualification, Length Of Years In Marriage And Age. Specifically, The Following Research Questions Were Raised As Pivots Upon Which The Study Revolved.

\section{Research Questions}

1) What Are The Role Of Spouses In Marital Stability As Perceived By Educated Couples In Kwara State?

2) Is There Any Difference Between Male And Female Educated Couples In Kwara State In Their Perception Of The Role Of Spouses In Marital Stability?

3) Are There Differences Among Educated Couples In Kwara State In Their Perception Of The Role Of Spouses In Marital Stability Based On Highest Educational Qualification?

4) Are There Differences Among Educated Couples In Kwara State In Their Perception Of The Role Of Spouses In Marital Stability Based On Length Of Years In Marriage?

5) Are There Differences Among Educated Couples In Kwara State In Their Perception Of The Role Of Spouses In Marital Stability Based On Age?

Research Hypotheses

1) There Is No Significant Difference Between Male And Female Educated Couples In Kwara State In Their Perception Of The Role Of Spouses In Marital Stability.

2) There Is No Significant Difference Among Educated Couples In Kwara State In Their Perception Of The Role Of Spouses In Marital Stability Based On Highest Educational Qualification.

3) There Is No Significant Difference Among Educated Couples In Kwara State In Their Perception Of The Role Of Spouses In Marital Stability Based On Length Of Years In Marriage.

4) There Is No Significant Difference Among Educated Couples In Kwara State In Their Perception Of The Role Of Spouses In Marital Stability Based On Age.

The Study Was Limited To Educated Couples In Kwara State. All The Educated Couples In Kwara State Formed The Target Population For The Study. Nevertheless, The Study Sampled The Perception Of 132 Males And 168 Females.

\section{Research Design}

\section{METHODOLOGY}

The Research Design Adopted For This Study Was The Descriptive Survey Design. According To Dada And Idowu (2006), Descriptive Survey Design Generally Involves Collections Of Data From A Defined Population To Describe The Present Condition Of The Population Using The Variables Under Survey. Based On This, The Researchers Considered The Method As Being Appropriate To Use For The Present Study. It Is Being Used To Investigate The Role Of Spouses In Marital Stability. In Addition, Survey Design Would Facilitate Making Inferences From The Data Collected.

\section{SAMPLE AND SAMPLING PROCEDURE}

The Target Population For This Study Consisted Of All Educated Couples In Kwara State. Data Were Collected From A Simple Random Sampled Of 300 Respondents Consisting Of 132 Males And 168 Females. One Hundred (100) Respondents Were Chosen From Each Of The Three Senatorial Districts In Kwara State (I.E. Kwara North, South And Central). And Thus, A Total Of 300 Respondents Participated In The Study.

\section{INSTRUMENTATION}

The Instrument Used In Collecting Data For This Research Was Developed By The Researchers And It Was Tagged "Role Of Spouses In Marital Stability Questionnaire" (Rsimsq). Items In The Questionnaire Were Derived From Information Obtained From Review Of The Related Literature. The Instrument Has Two Sections, I.E. Sections 'A' And 'B'. Section 'A' Contains Personal Information Of The Respondents While Section 'B' Consisted Of Items On The Role Of Spouses In Marital Stability. The 4-Point Likert Type Response Format Was Adopted For Use In Section B, Thus:

Sa-Strongly Agree (4 Points);

A-Agree (3 Points);

D-Disagree (2 Points); 
Sd-Strongly Disagree (1 Point).

All Items Were Positively Structured. A Cut-Off Mark Of 75 Differentiated Those Who Have Positive Or Negative Perception On The Role Of Spouses For Marital Stability.

Psychometric Properties

\section{VALIDITY OF THE INSTRUMENT}

The Content Validity Of The Instrument Was Established Through Vetting By Five Experts In The Department Of Counsellor Education, University Of Ilorin. The Lecturers Have Useful Suggestions By Eliminating Irrelevant Items, Modifying Some And New Ones Were Eventually Added.

\section{RELIABILITY OF THE INSTRUMENT}

In Order To Establish The Reliability Of The Instrument Used For This Study, The Test Re-Test Method Was Adopted. The Researchers Administered The Instrument To 30 Samples Who Do Not Participate In The Real Study At An Interval Of Four Weeks. The Two Sets Of Scores Were Correlated Using Pearson Product Moment Correlation Co-Efficient Formula. A Correlation Co-Efficient Of 0.71 Was Obtained Which Was Considered An Appropriate Reliability Measure For An Instrument Of This Nature.

\section{SCORING PROCEDURE}

In Scoring The Items In The Questionnaire, The Four-Point Likert Type Rating Scale Was Adopted. This Method Was Adopted Since It Gives Respondents The Opportunity To Respond More Freely To Each Of The Items In The Instrument. The Personal Data Section Of The Instrument Was Scored Using Simple Frequency Counts And Percentage Distribution. For Section B Which Consists Of 30 Items On The Role Of Spouses In Marital Stability As Perceived By Educated Couples In Kwara State, The Scores Are As Follows: Scores Of 1 Point Is For Strongly Disagree (Sd), 2 Points For Disagree (D), 3 Points For Agree (A) And 4 Points For Strongly Agree (Sa). The Highest Possible Score For Any Item Is 4 And The Lowest Is 1. Consequently, The Highest Possible Score Obtained Was 120 (I.E. 4 X 30), While The Lowest Possible Score Obtainable Was 30 (I.E. 1 X 30). To Determine The Respondents' Perception Of The Role Of Spouses In Marital Stability, The Mean Of Obtainable Scores Of 1, 2, 3 And 4 Was Taken To Be 2.5. Since There Are 30 Items On The Role Of Spouses In Marital Stability, Therefore (2.5 X 30) $=75$ Was Taken To Be The Cut-Off Point For Determining Whether The Respondents Agreed With The Items On The Role Of Spouses In Marital Stability Or Not.

\section{METHOD OF DATA ANALYSIS}

Frequency Count And Simple Percentage Which Are Descriptive Statistics, Were Used To Compute The Personal Data Of The Respondents. And The T-Test And Analysis Of Variance (Anova) Statistics Was Used To Test The Four Generated Null Hypotheses, And Where A Significant Difference Existed In The Anova Results, The Duncan Multiple Range Test (Dmrt) Statistics Was Used As A Post-Hoc Test To Determine The Group(S), That Contributed To The Significant Difference. All Null Hypotheses Were Tested At 0.05 Alpha Level Of Significance.

\section{RESULTS}

Table 1: Summary Table Showing The Role Of Spouses In Marital Stability By Mean Scores And Ranking

\begin{tabular}{|l|l|l|l|}
\hline S/N & Role Of Spouses & Mean & Ranking \\
\hline 1. & Sexual & 19.10 & $1^{\text {st }}$ \\
\hline 2. & Financial & 19.09 & $2^{\text {nd }}$ \\
\hline 3. & Domestic & 16.15 & $3^{\text {rd }}$ \\
\hline 4. & Behavioural & 16.07 & $4^{\text {th }}$ \\
\hline 5. & Religious & 15.86 & $5^{\text {th }}$ \\
\hline 6. & Social & 15.09 & $6^{\text {th }}$ \\
\hline
\end{tabular}

\section{Sexual}

Sexual Role Includes Having Free And Regular Sexual Relationship Between Husband And Wife, Avoiding Marital Infidelity, Understanding One Another When Sexual Relationship Is Not Convenient For A Partner E.T.C., Financial Role Includes Prudence On The Part Of The Spouses, Adequate Financial Provision By The Husband For The Family Upkeep, Having A Common Pause E.T.C., Domestic Role Includes Regular Delicious And Timely Cooking Of Food For The Entire Family By The Wife, Helping The Wife In The Kitchen To Relief Her From Too Much Stress, Keeping The Environment Clean By Spouses E.T.C., Behavioural Role Includes Flexibility In The Implementation Of The Family's Laid Down Rules And Regulations, Endurance At 
All Times By The Spouses, Paying Attention To One Another During Discussion E.T.C., Religious Role Includes Faithfulness To One Another By Both Husband And Wife, Praying Together By The Spouses, Total Dependence On God For Provisions E.T.C. And Social Role Includes Effective Communication Between Spouses, Co-Operation Between Spouses At All Times On Things That Will Stabilize The Marriage, Respect And Submission On The Part Of The Woman To The Authority Of The Husband E.T.C.

Table 1 Shows The Mean Scores And Rank Order Of The Role Of Spouses In Marital Stability. According To The Responses Of The Respondents, The Most Important Role To Be Played By The Spouses For Marital Stability Is Sexual With A Mean Score Of 19.10 Such As "Having Free And Regular Sexual Relationship Between Husband And Wife". The Second Role Is Financial With A Mean Score Of 19.09 Such As "Adequate Provision For The Entire Family On The Part Of The Husband". The Third Role Is Domestic With A Mean Score Of 16.15 Such As "Regular Delicious And Timely Cooking Of Food For The Entire Family By The Wife". The Fourth Role Is Behavioural With A Mean Score Of 16.07 Such As "Paying Attention To One Another During Discussion". The Fifth Role Is Religious With A Mean Score Of 15.86 Such As "Constant Reading Of The Scripture By The Spouses". While The Sixth Role Is Social With A Mean Score Of 15.09 Such As "Effective Communication Between Spouses".

Hypotheses Testing

Hypothesis 1:

There Is No Significant Difference Between Male And Female Educated Couples In Kwara State In Their Perception Of The Role Of Spouses In Marital Stability.

Table 2: The T-Test Analysis Of Male And Female Educated Couples In Kwara State In Their Perception Of The Role Of Spouses In Marital Stability.

\begin{tabular}{|l|l|l|l|l|l|l|}
\hline Gender & No & X & Sd & Df & $\begin{array}{l}\text { Cal. } \\
\text { T-Value }\end{array}$ & $\begin{array}{l}\text { Critical } \\
\text { T-Value }\end{array}$ \\
\hline $\begin{array}{l}\text { Male } \\
\text { Female }\end{array}$ & 133 & $\begin{array}{l}118.57 \\
75.70\end{array}$ & $\begin{array}{l}4.74 \\
20.56\end{array}$ & 298 & $2.35^{*}$ & 1.96 \\
\hline
\end{tabular}

$\mathrm{Nb}: *$ Significant At 0.05 Alpha Level Of Significance.

Table 2 Indicates That The Calculated T-Value Is 2.35 While The Critical T-Value Is 1.96. Since The Calculated T-Value Is Greater Than The Critical T-Value At 0.05 Alpha Level Of Significance, The Hypothesis Is Rejected, Which Means That There Is A Significant Difference Between Male And Female Educated Couples In Kwara State In Their Perception Of The Role Of Spouses In Marital Stability.

Hypothesis 2: There Is No Significant Difference Among Educated Couples In KwaraStateInTheirPerceptionOf The Role Of Spouses In Marital Stability Based On Highest Educational Qualification.

Table 3: Analysis Of Variance (Anova) Results Of Educated Couples In Kwara State In Their Perception Of The Role Of Spouses In Marital Stability Based On Highest Educational Qualification.

\begin{tabular}{|l|l|l|l|l|l|}
\hline Source Of Variance & $\begin{array}{l}\text { Sum Of } \\
\text { Squares (Ss) }\end{array}$ & $\begin{array}{l}\text { Degree Of } \\
\text { Freedom } \\
\text { (Df) }\end{array}$ & $\begin{array}{l}\text { Mean Square } \\
\text { (Ms) }\end{array}$ & $\begin{array}{l}\text { Cal. } \\
\text { F-Ratio }\end{array}$ & $\begin{array}{l}\text { Critical } \\
\text { F-Ratio }\end{array}$ \\
\hline Between Groups & 160453.1 & 2 & 80226.574 & & \\
Within Groups & 48779.038 & 297 & 164.239 & $4.88^{*}$ & 3.00 \\
Total & 209232.2 & 299 & & \\
\hline
\end{tabular}

$\mathrm{Nb}: *=$ Significant At 0.05 Alpha Level Of Significance

Table 3 Indicates That The Calculated F-Ratio Is 4.88 While The Critical

F-Ratio Is 3.00. Since The Calculated F-Ratio Is Greater Than The Critical F-Ratio At 0.05 Alpha Level Of Significance, The Hypothesis Is Rejected Which Means That There Is A Significant Difference Among Educated Couples In Kwara State In Their Perception Of The Role Of Spouses In Marital Stability Based On Highest Educational Qualification. Since There Is A Significant Difference Among Educated Couples Using Analysis Of Variance (Anova), The Researchers Proceeded To Use Duncan Multiple Range Test (Dmrt) As A Post-Hoc Test To Determine The Highest Educational Qualification $\operatorname{Group}(\mathrm{S})$ That Was Responsible For The Significant Difference Noted In The Anova Results In Table 3. 
Table 4:Duncan Multiple Range Test (Dmrt) Showing Differences In The Perception Of Educated Couples On The Role Of Spouses In Marital Stability Based On Highest Educational Qualification.

\begin{tabular}{|l|l|l|l|l|}
\hline $\begin{array}{l}\text { Duncan's } \\
\text { Grouping }\end{array}$ & Mean & Number & Group & $\begin{array}{l}\text { Highest } \\
\text { Qualification }\end{array}$ \\
\hline A & 119.69 & 100 & 1 & Gce, Wasse, Nce, Ond \\
\hline B & 82.40 & 154 & 2 & First Degree \\
\hline C & 43.48 & 24 & 4 & Ph.D \\
\hline D & 24.39 & 22 & 3 & Masters' Degree \\
\hline
\end{tabular}

In Table 4, Duncan Multiple Range Test (Dmrt) Results Was Used To Determine Which Of The Highest Educational Qualification Group(S) Mean(S) That Led To The Significant Difference Noted In The Anova Results Of Table 3. The Dmrt Results Indicated That Group 1 With A Mean Score Of 119.69 Differed Significantly From Groups 2,4 And 3 With Mean Scores Of 82.40, 43.48 And 24.39 Respectively. Group 2 With A Mean Score Of 82.40 Differed Significantly From Groups 1,4 And 3 With Mean Scores Of 119.69, 43.48 And 24.39 Respectively. Group 4 With A Mean Score Of 43.48 Differed Significantly From Groups 1,2 And 3 With Mean Scores Of 119.69, 82.40 And 24.39 Respectively. Group 3 With A Mean Score Of 24.39 Differed Significantly From Groups 1,2 And 4 With Mean Scores Of 119.69, 82.40 And 43.48 Respectively. Hence, The Significant Difference Noted In The Anova Results Of Table 3 Was As A Result Of The Fact That All The Groups Differed Significantly From One Another, Consequently, Hypothesis Two Was Rejected.

Hypothesis 3: There Is No Significant Difference Among Educated Couples In Kwara State In Their Perception Of The Role Of Spouses In Marital Stability Based On Length Of Years In Marriage.

Table 5: The T-Test Analysis Of Educated Couples In Kwara State In Their Perception Of The Role Of Spouses In Marital Stability Based On Length Of Years In Marriage.

\begin{tabular}{|l|l|l|l|l|l|l|}
\hline $\begin{array}{l}\text { Length Of Years In } \\
\text { Marriage }\end{array}$ & No & X & Sd & Df & $\begin{array}{l}\text { Cal. } \\
\text { T- } \\
\text { Value }\end{array}$ & $\begin{array}{l}\text { Critical } \\
\text { T-Ratio }\end{array}$ \\
\hline 0-30 Years & 128 & 39.6641 & 0.77640 & 298 & & \\
31 And Above Years & 172 & 25.1105 & 8.53233 & & 1.92 & 1.96 \\
\hline
\end{tabular}

Table 5 Indicates That The Calculated T-Value Is 1.92 While The Critical T-Value Is 1.96. Since The Calculated T-Value Is Less Than The Critical T-Value At 0.05 Alpha Level Of Significance, The Hypothesis Is Accepted, Which Means That There Is No Significant Difference Among Educated Couples In Kwara State In Their Perception Of The Role Of Spouses In Marital Stability Based On Length Of Years In Marriage.

Hypothesis 4: There Is No Significant Difference Among Educated Couples In Kwara State In Their Perception Of The Role Of Spouses In Marital Stability Based On Age Group.

Table 6: Analysis Of Variance (Anova) Results Of Educated Couples In Kwara State In Their Perception Of The Role Of Spouses In Marital Stability Based On Age.

\begin{tabular}{|l|l|l|l|l|l|}
\hline Source Of Variance & $\begin{array}{l}\text { Sum Of } \\
\text { Squares (Ss) }\end{array}$ & $\begin{array}{l}\text { Degree Of } \\
\text { Freedom } \\
\text { (Df) }\end{array}$ & $\begin{array}{l}\text { Mean Square } \\
\text { (Ms) }\end{array}$ & $\begin{array}{l}\text { Cal. } \\
\text { F-Ratio }\end{array}$ & $\begin{array}{l}\text { Critical } \\
\text { F-Ratio }\end{array}$ \\
\hline Between Groups & 181999.1 & 3 & 60666.365 & $6.59^{*}$ & 2.60 \\
Within Groups & 27233.093 & 296 & 92.004 & & \\
Total & 209232.2 & 299 & & \\
\hline
\end{tabular}

$\mathrm{Nb}: *$ Significant At 0.05 Alpha Level Of Significance

Table 6 Indicates That The Calculated F-Ratio Is 6.59 While The Critical F-Ratio Is 2.60. Since The Calculated F-Ratio Is Greater Than The Critical F-Ratio At 0.05 Alpha Level Of Significance, The Hypothesis Is Rejected Which Means That There Is A Significant Difference Among Educated Couples In Kwara State In Their Perception Of The Role Of Spouses In Marital Stability Based On Age Group. Since There Is A Significant Difference Among Educated Couples Using Analysis Of Variance (Anova), The Researchers 
Proceeded To Use Duncan Multiple Range Test (Dmrt) As A Post-Hoc Test To Determine The Age Group(S) That Led To The Significant Difference Noted In The Anova Results In Table 6.

Table 7: Duncan Multiple Range Test (Dmrt) Showing Differences In The Perception Of Educated Couples On The Role Of Spouses In Marital Stability Based On Age.

\begin{tabular}{|l|l|l|l|l|}
\hline $\begin{array}{l}\text { Duncan's } \\
\text { Grouping }\end{array}$ & Mean & Number & Group & $\begin{array}{l}\text { Highest } \\
\text { Qualification }\end{array}$ \\
\hline A & 120.00 & 75 & 1 & $15-20$ Years \\
\hline B & 105.70 & 117 & 2 & $21-30$ Years \\
\hline C & 83.27 & 46 & 3 & $31-40$ Years \\
\hline D & 51.85 & 62 & 4 & 41 And Above Years \\
\hline
\end{tabular}

In Table 7, Duncan Multiple Range Test (Dmrt) Results Was Used To Determine Which Of The Age Group(S) Mean(S) That Led To The Significant Difference Noted In The Anova Results Of Table 6. The Dmrt Results Indicated That Group 1 With A Mean Score Of 120.00 Differed Significantly From Groups 2, 3 And 4 With Mean Scores Of 105.70, 83.27 And 51.85 Respectively. Group 2 With A Mean Score Of 105.70 Differed Significantly From Groups 1, 3 And 4 With Mean Scores Of 120.00, 83.27 And 51.85 Respectively. Group 3 With A Mean Score Of 83.2609 Differed Significantly From Groups 1, 2 And 4 With Mean Scores Of 120.00, 105.70 And 51.85 Respectively. Group 4 With A Mean Score Of 51.85 Differed Significantly From Groups 1, 2 And 3 With Mean Scores Of 120.00, 105.70 And 83.27 Respectively. Therefore, The Significant Difference Noted In The Anova Results Of Table 6 Was Due To The Fact That All The Groups Differed Significant From One Another, Thus, Hypothesis Four Was Rejected.

\section{DISCUSSION OF FINDINGS}

The Results Of The Study Revealed That Educated Couples In Kwara State Are Similar In Their Perception On The Role Of Spouses Based On Length Of Years In Marriage, While Significant Difference Existed Based On Gender, Highest Educational Qualification And Age.

The First Null Hypothesis Showed That There Is A Significant Difference Between Male And Female Educated Couples In Kwara State In Their Perception Of The Role Of Spouses In Marital Stability. The Outcome Of This Finding Corroborates The Finding Of Joseph Et Al (2006) Which Revealed That A Significant Difference Existed In The Responses Of The Respondents Including Spouses In Their Perception Of Role Of Married People In Marital Stability. The Plausible Reason For The Outcome Of This Finding Might Be Because The Respondents Had Different Opinion As Regards The Role Of Spouses In Marital Stability, And Consequently, A Significant Difference Existed In Their Responses. Nevertheless, This Finding Negates The Finding Of Dada And Idowu (2006) Which Showed That Both Male And Female Respondents Including Spouses Had Similar Opinion In Their Role Of Spouses In Marital Stability.

Hypothesis Two Showed A Significant Difference Among The Respondents In Their Perception On The Role Of Spouses In Marital Stability Based On Highest Educational Qualification. This Finding Is In Line With The Finding Of Olson And Defrain (2000) Which Equally Showed A Significant Difference In The Responses Of The Respondents Including Married People In Their Role Of Spouses In Marital Stability. The Likely Reason For The Outcome Of This Finding Might Be Due To The Fact That Since The Respondents Differed In Their Highest Educational Qualifications, There Is The Likelihood That They Might Have Divergent Views In Their Role Of Spouses In Marital Stability. However, This Finding Negates The Finding Of George (2002) Which Revealed That A Significant Difference Does Not Exist In The Responses Of The Respondents In Their View Of The Role Of Spouses In Marital Stability.

Hypothesis Three Results Showed That The Responses Of The Respondents Were Similar In Their Perception Of The Role Expected To Be Played By Spouses As Regards Marital Stability Based On Length Of Years In Marriage. This Finding Supports The Finding Of Dada And Idowu (2006) Which Also Revealed That A Significant Difference Does Not Exist Among The Respondents In Their Perception Of The Role Of Spouses In Marital Stability. The Plausible Reason For The Outcome Of This Finding Might Be Due To The Fact That The Respondents Had Similar Experience Irrespective Of Their Length Of Years In Marriage, Consequently, They Had Similar Perception On The Role Of Spouses In Marital Stability. Nevertheless, This Finding Did Not Support The Finding Of Akpan (2002) Which Showed A Significant Difference In The Responses Of The Respondents Including Spouses In Their Expected Role Of Spouses In Marital Stability.

Hypothesis Four Revealed That There Is A Significant Difference Among Educated Couples In Kwara State In Their Perception Of The Role Of Spouses In Marital Stability On The Basis Of Age. This Finding Corroborates The Finding Of Gbenda And Akuime (2002) Which Revealed A Significant Difference Among The Respondents Including Spouses In Their Expected Role Of Spouses In Marital Stability Based On Age. The 
Likely Reason For The Outcome Of This Finding Might Be Because The Respondents Differed In Age, And Thus, They Might Perceive The Role Of Spouses For Marital Stability Differently Since They Belong To Different Age Group. And Consequently, A Significant Difference Existed In Their Responses. However, This Finding Is Not In Line With The Finding Of Agbana And Odewumi (2001) Which Does Not Show A Significant Difference In The Responses Of The Respondents Based On Age In Their Role Of Spouses In Marital Stability.

\section{CONCLUSION}

Based On The Findings Of The Study And The Discussion That Followed, The Following Conclusions Were Drawn.

1) There Was A Significant Difference Between Male And Female Educated Couples In Kwara State In Their Perception Of The Role Of Spouses In Marital Stability.

2) There Was A Significant Difference Among Educated Couples In Kwara State In Their Perception Of The Role Of Spouses In Marital Stability Based On Highest Educational Qualification.

3) There Was No Significant Difference Among Educated Couples In Kwara State In Their Perception Of The Role Of Spouses In Marital Stability Based On Length Of Years In Marriage.

4) There Was A Significant Difference Among Educated Couples In Kwara State In Their Perception Of The Role Of Spouses In Marital Stability Based On Age Group.

\section{IMPLICATIONS FOR COUNSELLING / RECOMMENDATIONS}

Professional Counsellors Should Intensify Efforts To Set Up Clinics Where Intending Spouses Can Be Given Pre-Marital And Marital Counselling On How They Can Relate Well With Each Other To Stabilize Their Marriage And Consequently Have A Blissful Marital Life.

The Professional Counsellors Can Equally Give Seminars To Intending Spouses On The Role They Are Expected To Play In Stabilizing Their MarriagesGovernment At All Levels Especially The Federal Government Should Take Urgent Step By Formulating Policies On The Role Of Spouses For Marital Stability.

\section{REFERENCES}

[1] Agbana, E.O. \& Odewumi, S.O. (2001). Married People And Stability At Home: Nigerian Journal Of Gender And Development, 2(1), 149-153.

[2] Akpan, C.P. (2002). Marital Communication. In. E.A. Uwe \& A.E. Obot, (Eds.). Marriage Counselling: Issues And Solutions. Calabar, Nigeria: Pyramid Printers.

[3] Anameze, L. N. (1996). Marriage Among Igbos: An Analytical Studs Of Past And Present Practices. Enugu: Cpa \& Gold Productions.

[4] Dada, M.F., \& Idowu, A.I. (2006). Factors Enhancing Marital Stability As Perceived By Educated Spouses In Ilorin Metropolis. The Counsellor, 22, 127-138.

[5] Gbenda, B. \& Akume, G. (2002). Resolving Marital Conflict Through Counselling. The Counsellor, 19(1), 25-34.

[6] George, I.N. (2002). Marital Role Adjustment And Satisfaction Among Ibibio Workers In Akwa Ibom State. Unpublished Ph.D Dissertation, Faculty Of Education, University Of Calabar, Calabar.

[7] George, I.W. (2004). Stress Management Among Nigerian Couples. The Counsellor, 14(1), 133-140.

[8] Joseph B.B., Maria, O.A.,Alberta, O.A., \& Imo E.U. (2006). Determinants Of Family Stability Among Married People In Cross River State, Nigeria. The Counsellor, 22, 82-90.

[9] Kanu, C.M., \& Anyanwu, K.A. (2006). Distress Signals In Marriage And Family Life: Implications For Guidance And Counselling. The Counsellor 22, 40-46.

[10] Mba: C. S. (1994). Towards A Successful Marriage And Family Life. Enugu: Biggard Memorial Seminary Press.

[11] Nwoye, A. (1991). Marriage And Family Counselling. Jos: Fab Anieh Nig Ltd.

[12] Olson, D.H. \& Defrain, J. (2000). Marriage And The Family Diversity And Strengths. London: Mayfrield Publishing Company. 